El Plan ahora un mar dorado en que nos calentamos como mazorcas al sol cuaresmal.

\title{
SA TUNA
}

Hacia sí misma la cala se recoge, lanza luces desde la coda del invierno, varas en inquieto abandono.

Entre la madera turbia y las barcas gira un aire de aceite crudo, de luz desmantelada.

Sonreímos y nos abrazamos.

Caminamos entre mesas y gente en el hervidero y el pescado.

Eso que fuimos.

Hoy la terraza es un garaje abierto sin nada más que nosotros y una bicicleta roja recargada en el muro. 